\title{
Employment Change and Business Prospects in Serbia ${ }^{3}$
}

Article history

Received: 06. August 2013

Sent for revision: 06. August 2013

Received in revised form: 30. September 2013

Accepted:30. September 2013

Available online: 06. November 2013

\begin{abstract}
The aim of this article is to examine whether some previous knowledge about business prospects affects companies' decisions about new employment in Serbia. In order to investigate this assumption a set of firm level data for 2012 is used. Following the theoretical approach that put an employer in a position to make various decisions about employment within the company, the trichotomous logit model is employed for the estimation of outcomes of possible companies' decisions with respect to a set of independent variables. We find that the level of employment in the year that precedes companies' decisions and relative changes in the number of employees in two successive years, as well as age and size of the company to some extent, affect companies' decisions about new employment. The most important finding of our research is that the companies that experienced fluctuations in the number of employees and upgraded their business opportunities in the previous period hesitate to make decisions on the engagement of new workers, whereas those companies that lost some business opportunities rather decide to downsize the total number of employees.
\end{abstract}

Keywords: Company, decision, employees, employment, Serbia, trichotomous logit model.

\footnotetext{
${ }_{1}^{1}$ Institute of Economic Sciences, Belgrade, kosovka.ognjenovic@ien.bg.ac.rs

2 Institute of Economic Sciences, Belgrade, aleksandra.brankovic@ien.bg.ac.rs

${ }^{3}$ This paper is part of research projects: 47009 (European integrations and social and economic changes in Serbian economy on the way to the EU) and 179015 (Challenges and prospects of structural changes in Serbia: Strategic directions for economic development and harmonization with EU requirements), financed by the Ministry of Education, Science and Technological Development of the Republic of Serbia.
} 


\section{Nova zaposlenost i poslovne mogućnosti u Srbiji}

Apstrakt: Cilj ovog rada je da ispita da li prethodna saznanja o poslovnim mogućnostima utiču na odluke preduzeća o novom zapošljavanju u Srbiji. Da bismo ispitali tu pretpostavku koristili smo skup podataka za 2012. godinu datih na nivou preduzeća. Sledeći teorijski pristup koji poslodavca stavlja na poziciju na kojoj donosi različite odluke o broju zaposlenih u svom preduzeću, koristili smo logit model trostrukog izbora za ocenjivanje ishoda koji su rezultat odluka preduzeća za dati skup nezavisnih promenljivih. Dobili smo da su nivo zaposlenosti u prethodnoj godini i relativne promene u broju zaposlenih u dve uzastopne godine, kao i starost i veličina preduzeća do određene mere, uticali na odluke preduzeća o novom zapošljavanju. Najznačajniji rezultat našeg istraživanja je da preduzeća, koja su imala iskustva sa fluktuacijama u broju zaposlenih i koja su unapredila svoje poslovne mogućnosti, oklevaju u donošenju odluka o angažovanju novih radnika, dok su odluke preduzeća koja su izgubila određene poslovne mogućnosti rezultovale smanjenjem broja zaposlenih.

Ključne reči: Logit model trostrukog izbora, odlučivanje, preduzeće, Srbija, zaposleni, zapošljavanje.

\section{Introduction}

Taking into account all the difficulties the economy of Serbia has been passing through over the years of prolonged transition, one can conclude that the corporate sector is not able to achieve a significant improvement in the absorption of the labour force. This can be confirmed by the low and insignificant rates of net employment that are partly result of the decreasing level of business activities, but also by slow changes in the rates of job creation and job destruction ( (Ognjenović \& Branković, 2012); (Vasić et al., 2011)). Nevertheless, companies in Serbia try to behave rationally, so they consider the changes in the level of business activity as an important factor of their individual plans for future recruitment of workers (Ognjenović \& Branković, 2010).

Certain analyses of the corporate sector in Serbia pointed out to the decreasing trend of business opportunities even for the well-established companies, while the surviving rates of new firms and sole traders also recorded diminishing rates (Ministry of Finance and Economy et al., 2012). The global economic crisis and its prolonged influence may be one of the reasons for this, but the long-term structural changes, which are mainly driven by transitional reforms, are equally important source of the difficulties (Filipović, 2012). The domestic credit growth as a percentage of the gross 
domestic product slightly increased after the beginning of the crisis (OECD et al., 2012), but obviously it was not enough for faster recovering of the corporate sector. There are analyses that point to serious financial problems of companies and to the persistent tendency of the low and insufficient profitability which cannot ensure the long-term stability of companies (Malinić, 2013).

The aim of the research presented in this article is to model and investigate whether previous knowledge about business prospects affects companies' decisions about job flows. In order to answer the main research questions a dependent variable with three unordered categories was created. Those categories are related to three independent decisions of companies which put them into three statuses. The first status refers to those companies that did not change the current level of employment, while statuses two and three comprise companies which decided to increase, i.e. to decrease, the current level of employment due to substantial changes in business prospects. We relabelled those statuses into statuses zero, one and two. The trichotomous logit model was employed for the estimation of outcomes of companies' decisions with respect to a set of independent variables. The analysis was conducted by using the 2012 Employer Survey data provided by the Public Employment Service of Serbia and the data taken from the Business Registers Agency.

This article includes the following sections. Section 2 provides background analysis covering the period that is important for investigating the main research questions. Section 3 provides a detailed description of the research methodology covering the methods used and the data analysed. Section 4 contains the main research results and provides their discussion, while the last section gives general conclusions.

\section{Background}

The economy of Serbia has experienced prominent changes since 2000 . These are consequences of the transitional processes, which have been associated with the changes in ownership and importance of certain sectors within the economy; but substantial, mostly negative, changes have also occurred due to the global economic crisis. One of the most severe problems in that regard is the constant rise in the number of unemployed.

Available indicators that can track effects of these factors on the performance of Serbian companies are few. The data publicly provided by the National Bureau of Statistics are scarce, while the Report on Small and Medium-Sized Enterprises and Entrepreneurship (SMEEs) does not cover a broad period, and is published once a year. 
According to the data from the Report on SMEEs (Ministry of Finance and Economy et al., 2012), although the number of business entities within the non-financial sector of the economy has increased in recent years, the indicators of business performance have deteriorated (Table 1). Namely, gross value added, turnover and profit decreased substantially in 2009 in relation to 2008, which was, probably, an immediate effect of the crisis. During the following year these indicators stagnated or somewhat increased, but again recorded negative year-to-year growth in 2011 .

Table 1. Selected indicators for the non-financial sector of the economy, year to year changes, in \%

\begin{tabular}{|l|c|c|c|c|c|c|c|}
\hline Indicator & 2005 & 2006 & 2007 & 2008 & 2009 & 2010 & 2011 \\
\hline No. of companies & -3.0 & -3.0 & 10.2 & 2.5 & 3.7 & 1.2 & 0.2 \\
\hline No. of employees & -0.1 & 0.4 & 0.3 & 1.1 & -6.5 & -6.2 & -1.8 \\
\hline Gross value added & 7.5 & 7.2 & 11.1 & 3.5 & -12.7 & 0.8 & -2.0 \\
\hline Turnover & -0.8 & 11.4 & 6.9 & 4.0 & -16.2 & 4.1 & -0.1 \\
\hline Profit & n.a. & n.a. & n.a. & n.a. & -8.4 & 11.4 & -2.1 \\
\hline
\end{tabular}

Source: (Ministry of Economy and Regional Development et al., 2009), (Ministry of Finance and Economy et al., 2012).

Given such unfavourable business conditions, companies could be expected to downsize their activities and/or to be reluctant to invest in the broadening of their businesses. Presented data seem to confirm these expectations, since the number of employees in the non-financial sector of the Serbian economy kept decreasing during three consecutive years.

This added up to the long-term problem of unemployment. Namely, just when the restructuring of the economy started to positively contribute to the decrease in the unemployment rate (2006-2008 period), indicators on the employment started to deteriorate again (Fig. 1). In just four years the unemployment rate increased by more than 10 percentage points, while the employment rate has stood below 50 percent for several years. In 2012 in relation to 2004 the number of employees aged 15-64 was down to 1.4 million, which is a decrease of nearly 600 thousand $^{4}$.

\footnotetext{
${ }^{4}$ The magnitude of the problem of low employment and high unemployment rates in Serbia is particularly pronounced when put in comparison with some other data, e.g. for the European Union. The employment and unemployment rates in the EU-27 in 2012 stood at $64.2 \%$ and $10.5 \%$, respectively, which is substantially better than in Serbia. However, in comparison with the goal set out by the Lisbon strategy, which envisaged employment rate to be $70 \%$ by 2010 , even the EU was underachiever. Sources: (Eurostat), (European Commission, 2010).
} 
Ognjenović K. et al.: Employment Change and Business Prospects in Serbia

Figure 1. Employment and unemployment rates for population $15-64$, in $\%$

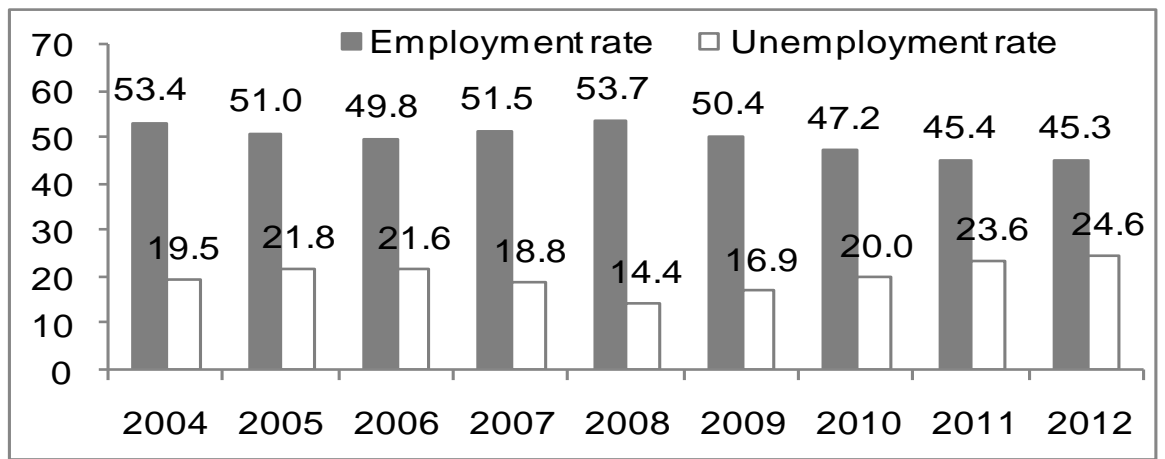

Source: National Bureau of Statistics, Labour Force Survey, various issues.

In the view of the striking decrease in the number of employees during the 2004-2012 period, several notable changes regarding the structure of employment should also be pointed out. As far as the ownership structure is concerned, the processes of privatisation and setting up of new companies led to the increase of the importance of the private sector. As given in Fig. 2, the share of the private entities in the number of employees aged between 15 and 64 years increased from 39 percent in 2004 up to 56 percent in 2008. Afterwards it slightly decreased, leading to the likely conclusion that dismissals of workers due to negative effects of the crisis has been practiced more in the private sector than in the state-owned one.

Figure 2. Employed persons aged 15-64 by the ownership structure, in \%

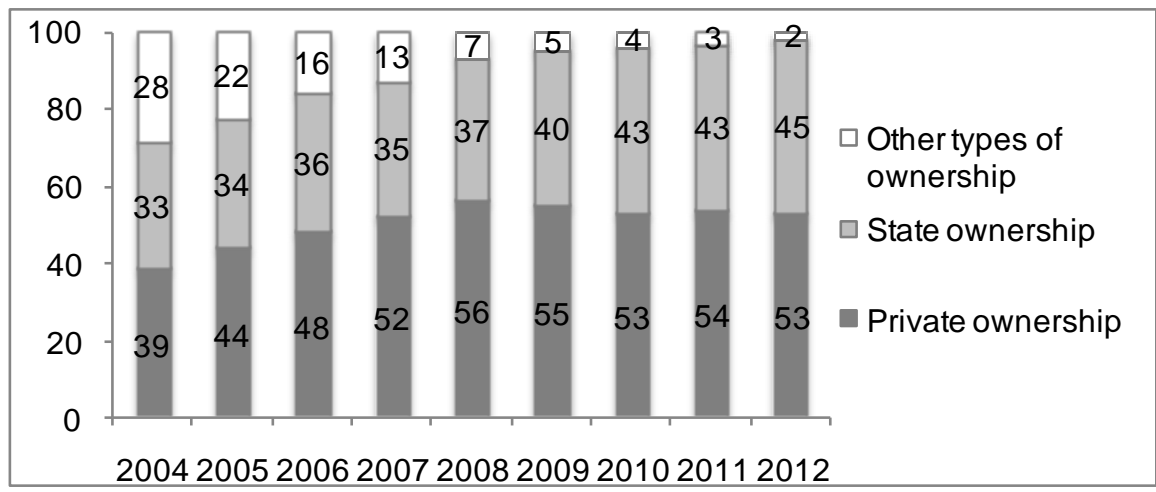

Source: National Bureau of Statistics, Labour Force Survey, various issues. 
In line with these findings could be those related to the changes in the structure of employment by activities during the same period. Activities in which the largest changes in the number of employees (15-64) have happened include those that are predominantly privately owned: manufacturing, agriculture and trade. On the other hand, activities that are dominantly state-owned, such as public administration, education and health and social services, recorded substantially lower decrease in the number of employees. A notion should be made that these data, illustrated in Table 2, should be observed with some caution, because figures for 2004 and 2012 are not fully compatible due to the changes in the classification of economic activities introduced in 2010. Having that in mind, one should interpret Table 2 as the illustration of the main tendencies.

Table 2. Employed persons aged 15-64 by activities, in 000

\begin{tabular}{|l|r|r|r|}
\hline & 2004 & 2012 & \multicolumn{1}{l|}{ Change in \% } \\
\hline Agriculture, forestry, fishing & 529.1 & 391.7 & -26.0 \\
\hline Manufacturing & 545.1 & 378.8 & -30.5 \\
\hline Construction & 151.7 & 114.2 & -24.7 \\
\hline Trade & 437.6 & 301.7 & -31.1 \\
\hline Transport and communications & 163.2 & 162.2 & -0.7 \\
\hline Financial and insurance activities & 44.8 & 42.1 & -6.0 \\
\hline Public administration & 169.4 & 117.7 & -30.5 \\
\hline Education & 148.7 & 150.9 & 1.4 \\
\hline Health and social work & 164.7 & 141.9 & -13.9 \\
\hline Other activities & 381.6 & 341.5 & -10.5 \\
\hline Total & $2,736.0$ & $2,142.7$ & -21.7 \\
\hline
\end{tabular}

Source: (National Bureau of Statistics, 2006), (National Bureau of Statistics, 2013).

\section{Research methodology}

\subsection{Methods}

The theoretical background for the analysis presented in this article is based on the economic theory of utility, i.e. of profit maximisation for a given amount of resources. More specifically, we observe the demand for labour from the point of view of an employer who makes various decisions about employment within the company (Hamermesh, 1993). Taking three possible decisions (alternatives) of companies, in relation to their business prospects, we have specified and estimated a qualitative response model with three outcomes 
(we will call them three statuses). Status zero is assigned to the group of companies which did not record changes in the number of employees as a reflection of changes in business prospects. Analogously, status one (two) is given to those companies which recorded positive (negative) net employment due to favourable (unfavourable) business prospects. Changes in the number of employees that may result from regular fluctuations of workers are not observed. Thus, in this article we observe how business prospects affect possibilities of companies in job creation and destruction.

Following notation provided by Greene (2000), the trichotomous logit model for companies' decisions about new employment can be specified as:

$$
R\left(y_{i}=j \mid x_{i}\right)=\exp \left(x_{i j}^{\prime} \beta_{j}\right) /\left[\sum_{l=0}^{2} \exp \left(x_{i}^{\prime} \beta_{l}\right)\right], j=0,1,2, i=1, \ldots, N
$$

In the equation (1), $x$ is a $(1+\mathrm{k})$-dimensional vector of individual-specific independent variables (predictors), including a vector of units as a first element, while $\beta_{j}$ is a $k$-dimensional vector of unknown coefficients that differs across alternatives. $j$ and $i$ are the numbers of alternatives and sample units, respectively. A general form of the model includes errors assumed to be independently and identically distributed across alternatives.

Then, based on the equation (1) the response probabilities for three possible outcomes (alternatives) are given as follows:

$$
\begin{aligned}
& \text { P } \left.y_{i}=j \mid x_{i}\right)=\exp \left(x_{i}^{\prime} \beta_{j}\right) /\left[1+\sum_{l=1}^{2} \exp \left(x_{i}^{\prime} \beta_{l}\right)\right], j=0,1,2, i=1, \ldots, N \\
& \text { P } \left.y_{i}=0 \mid x_{i}\right)=1 /\left[\sum_{l=1}^{2} \exp \left(x_{i}^{\prime} \beta_{l}\right)\right], j=1,2, i=1, \ldots, N, \beta_{0}=0
\end{aligned}
$$

where the probability determined by the equation (3) is known when we calculate probabilities for two other outcomes. This implies that the response probability of the outcome $\not\left(y_{i}=0 \mid x_{i}\right)$ was chosen as a baseline alternative, which further yields the normalization at $\beta_{0}=0$.

The log-odds ratio of the alternative $j$ relative to the baseline alternative in $x$ is given as:

$$
\frac{\partial \log R(y=j) / R(y=0)}{\partial x}=\beta_{j} .
$$


The expression (4) allows for direct interpretation of the coefficient estimates even if the magnitudes of the estimates are difficult to interpret (Greene, 2000). The maximum likelihood method of estimation provides consistent estimates of coefficients. Appropriate standard errors of the coefficient estimates are calculated by using the delta method.

In order to check for the assumption about error terms the appropriate tests are proposed (Hausman \& McFadden, 1984) and (Small \& Hsiao, 1984). Under the null hypothesis both of these tests test the assumption about the independence of irrelevant alternatives. Hence, by exclusion of irrelevant alternatives the coefficient estimates will not change substantially. More about the distribution of errors in the multinomial logit model is given in Greene (2000).

\subsection{Data}

The data used for the analysis presented in this article come from the Employer Survey that was carried out by the Public Employment Service in 2012 (Public Employment Service of Serbia, 2012). The first survey was carried out in 2011 (Vasić et al., 2011). The sample of companies for both surveys was selected by the National Bureau of Statistics. Only companies with more than 10 employees participated in the survey. These companies employ nearly 80 percent of the total number of employees. However, the structure of the total employment in Serbia somewhat differs if self-employed and small family firms, which are exempt from the sample, are observed. The shares of self-employed, employees and family workers in the total employment are respectively 22, 70 and 8 percent (National Bureau of Statistics, 2012). Additionally, the sample represents companies by their ownership structure, by sectors of economic activities (public services such as education and health, state administration and alike are excluded from the sample) and by the regional distribution (the Kosovo and Metohija region is excluded from the sample due to low response rates). A total of 4,027 companies responded to the survey. However, the data available in the survey were not sufficient for the purpose of the analysis presented in this article, so we combined the survey data with the data provided by the Business Registers Agency (Business Registers Agency, 2013).

In order to ensure a theoretical expression of our model, the set of independent variables, which is based on the limited source of information, can be divided into two subsets of variables, continuous and categorical. The first subset includes a variable that represents the amount of engaged labour, i.e. a total number of employees in the year that precedes companies' decisions about new employment ( $L n$ _emp), the variable that measures relative changes in the number of employees in two successive years and in a certain way approximates the influence of structural changes on job flows (Ch_emp) and age of a company divided by 10 (Age_10). The data about age of the company are retrieved from 
the web site of the Business Registers Agency. However, due to some changes in the ownership structure that were initiated by regulation during the 1980 s and 1990s, the data about age of the company may not correspond to the exact number of years of age, in particular for large-sized companies. Keeping in mind that large-sized companies represent only 7.2 percent of the sample we have neglected this fact (Table 3). The current Law on Business Entities still recognizes forms of companies which operate with social or state capital (Official Gazette of the Republic of Serbia, 36/2011, 99/2011).

Table 3 provides means and standard deviations of the independent variables that are used in the trichotomous logit model. The data are processed and analysed using Stata.

Table 3. Descriptive statistics of the independent variables

\begin{tabular}{|c|c|c|}
\hline Independent Variable & Mean & Standard deviation \\
\hline Ln_emp & 3.605 & 1.171 \\
\hline Ch_emp & 1.097 & 42.045 \\
\hline Age_10 & 1.485 & 0.913 \\
\hline \multicolumn{3}{|l|}{ Size of firm } \\
\hline Small & 0.671 & 0.470 \\
\hline Medium & 0.257 & 0.437 \\
\hline Large & 0.072 & 0.258 \\
\hline \multicolumn{3}{|l|}{ Region } \\
\hline Belgrade & 0.113 & 0.316 \\
\hline Vojvodina & 0.318 & 0.466 \\
\hline Sumadija_west & 0.330 & 0.470 \\
\hline South_east & 0.239 & 0.427 \\
\hline \multicolumn{3}{|l|}{ Economic activity } \\
\hline Agriculture & 0.083 & 0.276 \\
\hline Industry & 0.341 & 0.474 \\
\hline Construction & 0.112 & 0.316 \\
\hline Business_services & 0.352 & 0.478 \\
\hline Other_services & 0.110 & 0.314 \\
\hline \multicolumn{3}{|l|}{ Ownership } \\
\hline Private & 0.918 & 0.275 \\
\hline Public & 0.049 & 0.215 \\
\hline Other & 0.034 & 0.181 \\
\hline No. of observations & \multicolumn{2}{|c|}{4027} \\
\hline
\end{tabular}

Source: Authors' calculation. 
The second subset includes four categorical variables. The variable size of the firm, which is classified according to three criteria (the number of employees, total annual turnover and average annual balance sheet) prescribed by the Accounting and Auditing Law (Official Gazette of the Republic of Serbia, 46/2006, 111/2009, 99/2011), is composed of three dummy variables (large-sized companies are the reference category). The variable region includes four dummies (the Southern and Eastern Serbia region is the reference category), and the variable economic activity encompasses activities such as industry (B, C, D, E), construction ( $F)$, business services ( $G, H, I, J, K, L)$, and other services (M, N, Q, R), while the economic activity of agriculture, forestry and fishing $(A)$ is the reference category. The classification of economic activities, based upon NACE rev. 2, is provided by the National Bureau of Statistics (Vasić et al., 2011). The last categorical variable included in the model is ownership structure and includes three dummies (other forms of ownerships are the reference category).

Fig. 3 shows the frequency distribution of a dependent variable. We created the dependent variable with three unordered categories. These categories are associated with three independent statuses of companies (alternatives). Status zero (Status $=0$ ) corresponds to those companies which recorded no changes in the number of employees due to unchanged business prospects, while status one (Status $=1$ ) encompasses companies which increased the number of employees due to favourable business prospects, and status two (Status $=2$ ) comprises companies which experienced dismissals due to unfavourable business conditions. Status zero is the reference alternative.

Figure 3. Frequency distribution of the dependent variable

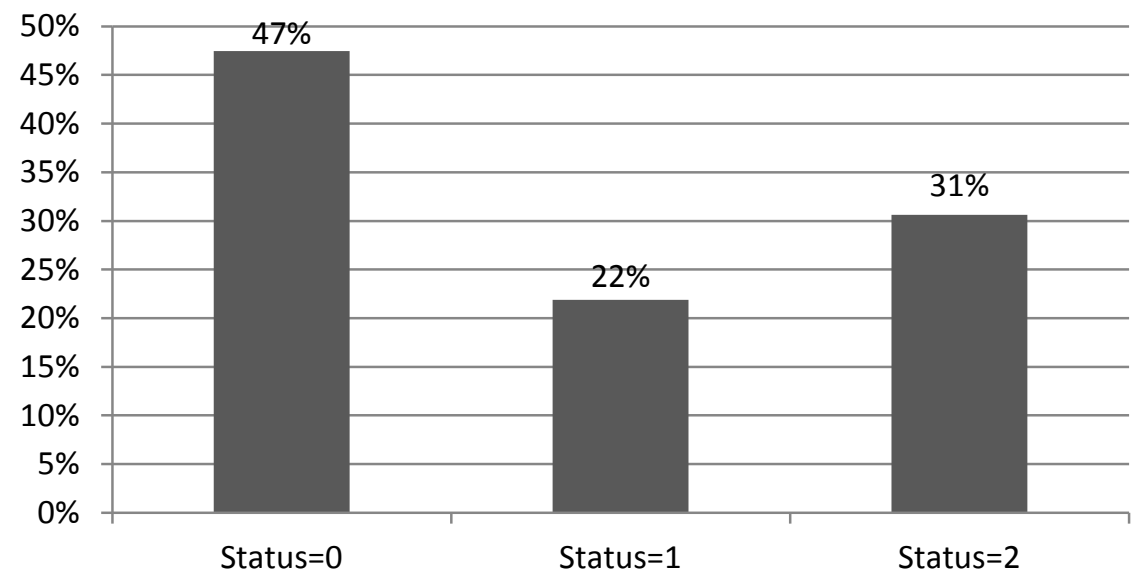

Source: Author's calculation. 
The dependent variable is created based on direct questions in which companies were asked to provide information about the inflow of workers due to favourable business prospects, as well as about the outflow of workers due to unfavourable business prospects. The status zero is derived from the answers of those companies that had not experienced changes in employment due to associated changes in their business prospects.

\section{Empirical results and discussion}

The estimates of the trichotomous logit model for three independent statuses of companies in regard to their decisions about employment in 2011 are recorded in Table 4 below. The estimated trichotomous logit model correctly predicts 57.66 percent of probabilities, so the model can be used for predictions of companies' decisions about job flows. Additionally, the model reduces 30.61 percent of error still remaining relative to the modal alternative. Our modal alternative lies in the baseline alternative, i.e. in a status that classifies companies as those that did not change the number of employees due to unchanged business prospects. The results of the test for testing the assumption about the independence of irrelevant alternatives are satisfactory, indicating that the log odds of one relative to the baseline alternative are independent of remaining alternatives. We presented the results of the Suestbased test that is a modification of the Hausman and McFadden test (Hausman \& McFadden, 1984).

The intercept terms have negative signs and are statistically significant in the estimated model. A negative sign of the intercepts reflects the skewness towards the modal alternative. This means that the largest number of companies' decisions was related to that one which was not resulted in changes in the number of employees due to unchanged business opportunities. This finding is in line with the expectations of companies about job flows for the same year (Ognjenović, 2013). The expected distribution of alternatives for 2011 that includes no changes, increase and decrease in employment due to changes in business prospects was as follows: 55,31 , and 14 percent, respectively. Comparing the expected with the actual distribution of companies' decisions for 2011 we can see in Fig. 3 above that no significant changes in the baseline alternative are present, while more companies destroyed jobs due to bad business opportunities than created new jobs as a result of improved business opportunities. In addition, there are findings that support this conclusion showing that no significant changes in the net employment rates are present among companies in Serbia (Ognjenović \& Branković, 2012).

The level of the engaged labour in the previous period significantly affects companies' decisions about both new employment and reduction of the 
current level of employees. This means that finding a new business opportunity is followed by large difficulties, as well as that companies perceive labour as a burden not as a resource. An additional worker associated with the firms that have deteriorated business prospects affects companies' decisions to decrease the number of employees in the current year over the baseline alternative by the log odds of 1.4 ceteris paribus. This is in line with some earlier results on gross job flows that confirm that the economy of Serbia creates and destroys around seven percent of jobs simultaneously (Ognjenović \& Branković, 2012).

Relative changes in the number of employees for two successive years that approximate the influence of structural changes have diverse effects on companies with favourable and with unfavourable business prospects as it was expected. Those companies which experienced fluctuations of workers in the previous period, but had improved business prospects, are more cautious in making decisions about new employment. They would rather not change the current level of employees. However, those companies that lost business opportunities and previously experienced fluctuations of workers were more likely to reduce the current level of employment by the log odds of 1.0 instead of deciding not to change it. Both estimates are statistically significant at the 1 percent level.

We decided to include the variable years of age of a company into the model because there is a common belief that older companies are more experienced in attracting new business opportunities. One additional year of age increases the log odds by 1.0 ceteris paribus, but the estimate is not statistically significant. Furthermore, one additional year of age for those companies which have poor business opportunities decreases the log odds by 0.9 ceteris paribus, meaning that older companies are less likely to decrease the number of employees over the baseline alternative. The estimate is statistically significant at the 10 percent level. Similar analysis on business opportunities points to insufficient dynamics of founding new firms and the prevalence of closed businesses (Ministry of Finance and Economy et al., 2012).

Size of companies did not determine their decisions about new employment, while it was important factor for those companies which decided to reduce the number of employees due to deteriorated business conditions instead of not to change it. This decision was equally important for both small- and mediumsized companies compared to the large-sized ones. Both estimates are statistically significant at the conventional levels. 
Ognjenović K. et al.: Employment Change and Business Prospects in Serbia

Table 4. Estimates of the trichotomous logit model

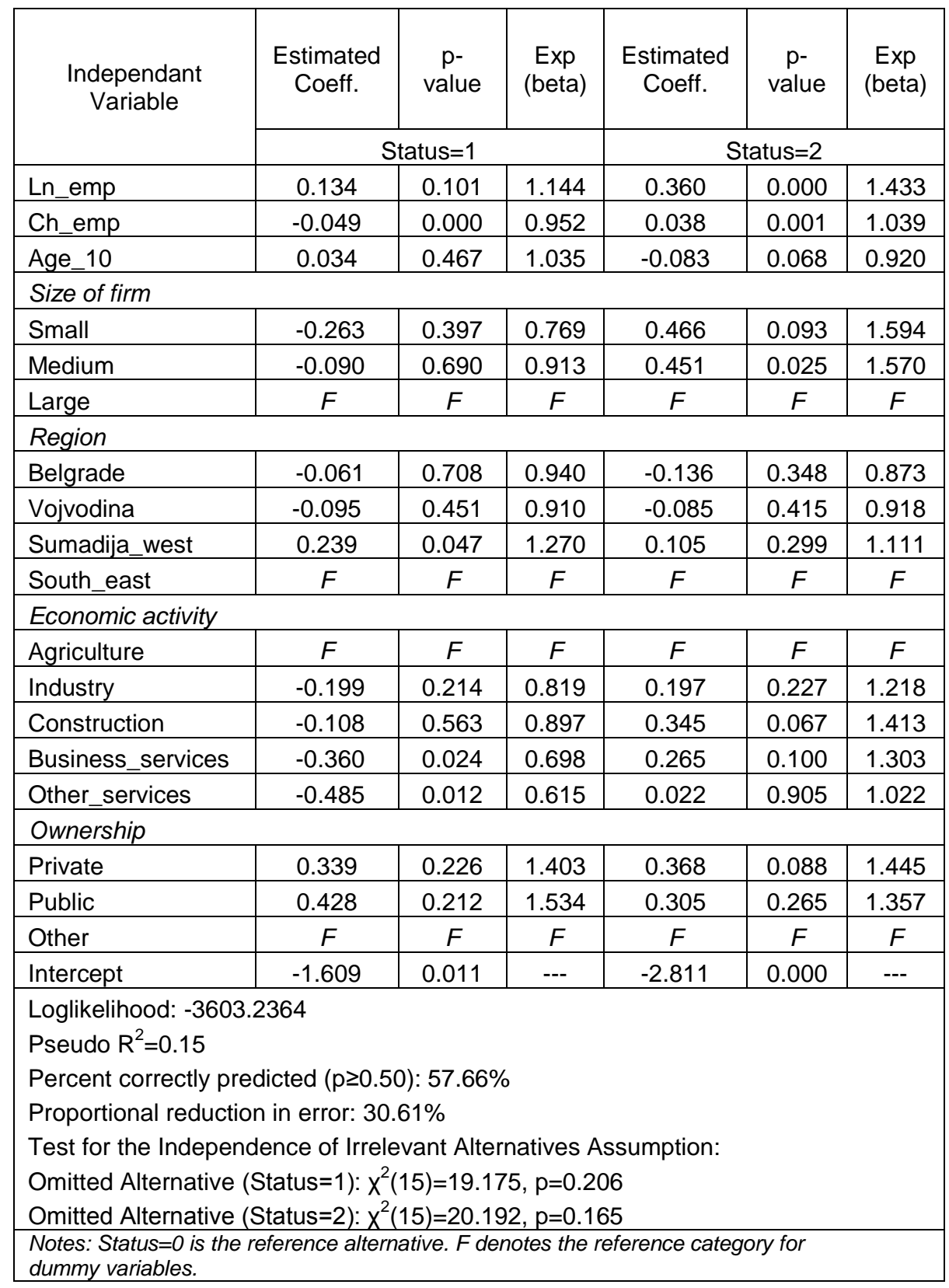

Source: Authors' calculation.

Industrija, Vol.41, No.3, 2013 
The regional distribution of companies is not found to be important for making decisions about job flows. Compared to the Southern and Eastern Serbia region, only companies from the Šumadija and Western Serbia region recorded certain fluctuations of workers. Companies from this region were 1.3 times more likely to increase the number of employees due to favourable business conditions compared to the baseline alternative ceteris paribus. The estimated coefficient is statistically significant at the 5 percent level. Also, in the same region there were companies which, due to lost business opportunities, decided to reduce employment rather than opting for the baseline alternative, but the estimate is not statistically significant.

Taking the economic activity of agriculture, forestry and fishing as a reference category, we can conclude that companies which pursue their business activities in all other economic sectors decided not to change the number of employees rather than to increase it. These decisions were especially important for companies which provide business and other services. The estimated coefficients are statistically significant at the 5 percent level. In contrast, companies operating in construction had the worst business opportunities and as a result they were 1.4 times more likely to reduce the number of employees than not to change it ceteris paribus. The decisions of companies, related to the reduction of employment due to unfavourable business prospects, in other economic sectors were not statistically significant. By using the analysis of financial performance measures across the sectors of economic activity, Malinić (2013) finds that the most unfavourable sectors in terms of debt to equity ratio are manufacturing, construction and retail trade. The author concludes that the economy of Serbia encountered a significant cumulative decrease in business activity and deterioration of financial performances which are not only the result of the recent economic crisis.

The ownership structure was not important in making decisions about new employment, while privately-owned companies were 1.4 times more likely to decide to reduce employment instead of choosing the baseline alternative ceteris paribus. The estimate is statistically significant at the 10 percent level. Vasić et al. (2011) find that the private companies are more determined to change the level of employment in both directions, whereas the public companies are more restrained in that regard. When the period of bad business opportunities arises, the demand for labour will be additionally constrained.

Table 5 below contains the results of the Wald test for testing the joint significance of the explanatory variables across alternatives. The coefficients of dummy variables for region and ownership, as well as for certain economic sectors are not jointly significant across alternatives, but we decided to leave those variables in the model because they were at least significant for one of 
Ognjenović K. et al.: Employment Change and Business Prospects in Serbia

the observed alternatives. All other coefficients are jointly significant at the conventional levels.

Table 5. Wald test for the joint significance of the independent variables

\begin{tabular}{|c|c|c|c|}
\hline Independent Variable & $x^{2}$ & $\mathrm{df}$ & $\mathrm{p}$-value \\
\hline Ln_emp & 25.853 & 2 & 0.000 \\
\hline Ch_emp & 639.805 & 2 & 0.000 \\
\hline Age_10 & 5.145 & 2 & 0.076 \\
\hline \multicolumn{4}{|l|}{ Size of firm } \\
\hline Small & 4.789 & 2 & 0.091 \\
\hline Medium & 6.380 & 2 & 0.041 \\
\hline Large & $F$ & $F$ & $F$ \\
\hline \multicolumn{4}{|l|}{ Region } \\
\hline Belgrade & 0.892 & 2 & 0.640 \\
\hline Vojvodina & 0.967 & 2 & 0.617 \\
\hline Sumadija_west & 4.178 & 2 & 0.124 \\
\hline South_east & $F$ & $F$ & $F$ \\
\hline \multicolumn{4}{|l|}{ Economic activity } \\
\hline Agriculture & $\mathrm{F}$ & $\mathrm{F}$ & $\mathrm{F}$ \\
\hline Industry & 3.833 & 2 & 0.147 \\
\hline Construction & 4.339 & 2 & 0.114 \\
\hline Business_services & 9.742 & 2 & 0.008 \\
\hline Other_services & 6.592 & 2 & 0.037 \\
\hline \multicolumn{4}{|l|}{ Ownership } \\
\hline Private & 3.762 & 2 & 0.152 \\
\hline Public & 2.371 & 2 & 0.306 \\
\hline Other & $F$ & $F$ & $F$ \\
\hline
\end{tabular}

Source: Authors' calculation.

In sum, the results presented in this article are in line with other research studies which pointed out to the issues of illiquidity and insolvency as one of the biggest problem of companies in Serbia (Nikolić et al., 2011). In addition, the low level of profitability and an increasing demand for financial restructuring of the corporate sector significantly deteriorated conditions for creation of new jobs in Serbia (Malinić, 2013). 


\section{Concluding remarks}

In this article we investigated whether previous knowledge about business prospects affects companies' decisions about the current level of employees. In order to do this we specified and estimated a trichotomous logit model. The estimated model fulfilled the assumption about the independence of irrelevant alternatives, implying that the log odds of one relative to the baseline alternative are independent of remaining alternatives and can be interpreted without cautions. The trichotomous logit model can be used for the prediction of companies' decisions about job flows, because the overall success rate of the estimated model is 58 percent. The data used for the analysis come from two sources, the 2012 Employer Survey of the Public Employment Service of Serbia and the Business Registers Agency.

The results of the estimated trichotomous logit model lead us to the following conclusions. The factors that most likely affect companies' decisions to employ new workers over the alternative that would not result in substantial changes in the number of employees are the level of the engaged labour in the previous period and the fact that companies pursue their businesses in the Šumadija and Western Serbia region. Other factors, such as relative changes in the number of employees in two successive years and business operations within the services sectors, rather contribute to the decision not to change the current number of employees than to increase it. In contrast, those factors that most likely contribute to the reduction in the current number of employees over the baseline alternative include the level of the engaged labour in the previous period, relative changes in the number of employees in two successive years, size of the firm, businesses associated with the economic sector of construction and private ownership of companies, while age of a company made the companies choose not to change the current level of employees instead of reducing it.

Finally, some caveats need to be mentioned. The empirical part of the analysis, due to certain limitations of the data used, does not cover micro and small family firms as well as sole traders. The state sector is limited to companies that provide subsidised and commercial services so that certain economic sectors are exempt from the analysis too.

The analysis presented in this article complements all previous research studies that examined the challenges and difficulties the corporate sector in Serbia faces. In addition, some policy implications arise from the empirical results obtained in the article. Small- and medium-sized privately-owned companies react faster to the outside changes than the large-sized and stated-owned companies, so that they are potential sources of a higher demand for labour. Overall environment for founding new firms is obviously not encouraging, as confirmed by a diminishing ratio between opened and 
closed businesses, so that this important source of the demand for labour is thin. The services sectors, in general, are more adaptable to the outside changes and show faster recovery after the economic crisis than construction or certain branches of manufacturing, illustrating different contributions to the potential demand for labour. Moreover, companies that experienced fluctuations in gross job flows and upgraded their business opportunities in the previous period hesitate in making decisions on the engagement of new workers, whereas those companies that lost some business opportunities rather decide to downsize the total number of employees. Those conclusions are helpful in understanding the low rates of job creation in Serbia.

\section{References}

- Accounting and Auditing Law. Official Gazette of Serbia, 46/2006, 111/2009, 99/2011. Retrieved from http://www.paragraf.rs .

- Business Registers Agency of Serbia. Database: Business Entities. Retrieved from http://www.apr.gov.rs/ (accessed on July 22-24, 2013).

- European Commission. (2010). Lisbon Strategy Evaluation Document. Commission Staff Working Document SEC (2010) 114 final. Retrieved from: http://ec.europa.eu/europe2020/pdf/lisbon_strategy_evaluation_en.pdf .

- Eurostat database. Retrieved from http://epp.eurostat.ec.europa.eu (accessed on September 28, 2013).

Filipović, M. (2012). "Sustainable Development of Serbia at the Beginning of the 21st Century". Industry, 40(1), 133-148.

Greene, H. W. (2000). Econometric Analysis, Fourth Edition. Upper Saddle River (USA): Prentice Hall International, Inc.

Hamermesh, D. S. (1993). Labor Demand. Princeton (USA): Princeton University Press.

Hausman, J., \& McFadden, D. (1984). "Specification Tests for the Multinomial Logit Model”. Econometrica, 52(5), 1219-1240.

- Law on Business Entities. Official Gazette of Serbia, 36/2011, 99/2011.Retrieved from http://www.paragraf.rs .

Malinić, D. (2013). "Insufficiency of Serbian Economy's Operating Performances: Manifestations, Causes and Main Guidelines of Recovery". Ekonomika preduzeća, 61(1-2), 41-62.

- Ministry of Economy and Regional Development of the Republic of Serbia, et al. (2009). Report on Small and Medium-Sized Enterprises and Entrepreneurship for 2008. Belgrade: Ministry of Economy and Regional Development of the Republic of Serbia, et al.

- Ministry of Finance and Economy of Serbia, et al. (2012). Report on Small and Medium-Sized Enterprises and Entrepreneurship for 2011. Belgrade: Ministry of Finance and Economy of Serbia, et al. Retrieved from http://narr.gov.rs/index.php/narr_en/Activities/Research-and-Analysis/Report-onSME .

- National Bureau of Statistics. (2006). Labour Force Survey 2004. Bulletin No. 451. Retrieved from http://www.stat.gov.rs . 
Ognjenović K. et al.: Employment Change and Business Prospects in Serbia

- National Bureau of Statistics. (2012). Statistical Yearbook 2012. Retrieved from http://www.stat.gov.rs .

- National Bureau of Statistics. (2013). Labour Force Survey 2012. Bulletin No. 564. Retrieved from http://www.stat.gov.rs .

Nikolić, I., Vučković, V., \& Živković, B. (2011). "Stanje nelikvidnosti i analiza predloga Zakona o sporazumnom finansijskom restrukturiranju privrednih društava”. Industry, 39(4), 181-191.

OECD, et al. (2012). SME Policy Index: Western Balkans and Turkey 2012: Progress in the Implementation of the Small Business Act for Europe. Paris: OECD Publishing. Retrieved from http://dx.doi.org/10.1787/9789264178861-en .

Ognjenović, K. (2013). Forthcoming "How Structural Changes Affect Enterprises' Expectations about Employment in Serbia?". Economic Analysis, 46(3-4).

Ognjenović, K., \& Branković, A. (2012)."Job Creation and Employment in a Time of Crisis”. In J.S. Andrade, C.N.M Simões, I. Stošić, D. Erić \& H. Hanić (Eds.), Managing Structural Changes: Trends and Requirements (pp. 375-396). Coimbra (Portugal): Faculty of Economics of the University of Coimbra.

Ognjenović, K., \& Branković, A. (2010). "Factors with Significant Impact on Individual Employment Plans of Enterprises: A Short-Term Assessment Based on Data of the Serbian Economy". In V. Šoltés, H. Hanić \& D. Erić (Eds.), Influence of Global Economic Crisis on CEE Region - Possible Way Out (pp. 120-128). Košice (Slovakia): Technical University of Košice / Belgrade Banking Academy Faculty for Banking, Insurance and Finance / Institute of Economic Sciences.

- Public Employment Service of Serbia. (2012). Database: Employer Survey. Belgrade: Public Employment Service.

Small, A. K., \& Hsiao, C. (1984). "Multinomial Logit Specification Tests". International Economic Review, 26(3), 619-627.

Vasić, V., Tancioni, M., \& Ognjenović, K. (2011). Labour Market Analysis and Forecasting Labour Market Needs in the Republic of Serbia. Belgrade: the Delegation of the European Union to the Republic of Serbia. Retrieved from http://www.eunes-project.eu/documents/C1_engleski_final.pdf. 